\title{
Native European branchiobdellids on non-native crayfishes: Report from the Czech Republic
}

\author{
Martin BLÁHA, , Filip LOŽEK, Miloš BUŘIČ, Antonín KOUBA, Pavel KOZÁK \\ University of South Bohemia in České Budějovice, Faculty of Fisheries and Protection of Waters, South Bohemian Research Center \\ of Aquaculture and Biodiversity of Hydrocenoses, Zátiší 728/II, CZ-389 25 Vodňany, Czech Republic \\ *Corresponding author: blaha@frov.jcu.cz
}

\begin{abstract}
Invasive alien species present a global threat to biodiversity, particularly where pathogens and symbionts are involved. Nonnative crayfish species can increase their impact on the host ecosystem through introductions of symbiotic fauna. Conversely, nonnative crayfishes could serve as hosts for native epibionts, thus substituting for disappearing native crayfishes as well. Here we report the presence of native branchiobdellids on naturalized populations of non-native crayfish Orconectes limosus and Pacifastacus leniusculus living in sympatry with native Astacus astacus. The native crayfish species probably served as a source of Branchiobdella spp. for non-native crayfishes. Two species of Branchiobdella (B. parasita and B. pentadonta) were found on P. leniusculus while only $B$. parasita was found on $O$. limosus. The level of colonization of inspected specimens and species was also evaluated. The mean number of branchiobdellids found on P. leniusculus and O. limosus was $26.0 \pm 15.9$, and $64.8 \pm 27.7$, respectively. Orconectes limosus was more heavily colonized by Branchiobdella despite being significantly smaller than P. leniusculus. Non-native species were corroborated as suitable to host the native epibionts.
\end{abstract}

Key words: Branchiobdella parasita; Branchiobdella pentadonta; ectosymbiont; signal crayfish; spiny-cheek crayfish; epibiosis.

Received: June 2017. Accepted: September 2017.

\section{INTRODUCTION}

Biological invasions generate ecological impacts challenging the conservation of biodiversity and natural resources (Dudgeon et al., 2006; Gallardo et al., 2016). Alien species which became invasive are impacting host ecosystems by their own activity. Additionally, they may add further concern through their associated symbionts which in turn infect native hosts (Prenter et al., 2004). Conversely, non-native organisms could serve as hosts for native symbionts (Carrillo et al., 2014). Branchiobdellida (Annelida: Clitellata) are ectosymbiotic clitellate worms living primarily upon freshwater crayfishes with a Holarctic distribution (Gelder and Williams, 2015). Eight Branchiobdella species are indigenous in Europe (Subchev, 2014). Together with their hosts - the signal crayfish Pacifastacus leniusculus (Dana, 1852), spiny-cheek crayfish Orconectes limosus (Rafinesque, 1817) and red swamp crayfish Procambarus clarkii (Girard, 1852), Nearctic (specifically North-American) branchiobdellidans were unintentionally introduced to the European continent. Thus, up to now only the nonnative branchiobdellidans, represented especially by species belonging to the genera Xironogiton (X. victoriensis Gelder \& Hall, 1990) and Cambarincola (C. gracilis Robinson, 1954, C. okadai Yamaguchi, 1933 and C. mesochoreus Hoffman, 1963), were recorded living on these non-native crayfishes from several European countries
(Gelder et al., 1994, 1999, 2012; James et al., 2015). Studies reporting the occurrence of Palearctic branchiobdellids on non-native crayfish species are very rare and Branchiobdella spp. occurring on $O$. limosus were reported only by Duriš et al. (2006) from the Elbe River, Czech Republic and by Vogt (1999) from the Steinbach brook, Germany. Gelder et al. (1999) reported Branchiobdella spp. on $P$. clarkii in Canale di San Grato, Martinetto, Italy. To our knowledge, no records of native branchiobdellids have been reported on naturalized populations of signal crayfish. Generally, although several branchiobdellid species could be found together on one crayfish specimen (Gelder and Williams, 2015), still the branchiobdellidans actively discriminate among sympatric hosts (Brown and Creed Jr, 2004) and there are many factors driving the decision whether to switch to another host or to stay on the original host. Most of these factors are linked to behaviour and general activity of potential hosts (Brown and Creed Jr, 2004; Farrell et al., 2014; Skelton et al., 2015). Additionally, their occurrence is not limited to crayfish, but branchiobdellidans have been reported on other crustaceans such as freshwater crabs or isopods (for details see Young, 1966; Keller, 1992). Thus, we evaluated the hypothesis that native branchiobdellids can be transmitted by and live on naturalized nonnative crayfish species populations of $O$. limosus and $P$. leniusculus living sympatrically with the native noble crayfish [Astacus astacus (Linnaeus, 1758)]. 


\section{METHODS}

Species of Branchiobdellida were sampled from crayfish caught during routine monitoring for non-native crayfish presence at two Czech localities in May, 2008. Thirty adult $O$. limosus were collected by hand in Černovický brook (N 49.309344 E 14.860639; geographic reference system WGS-84) as well as sixty $P$. leniusculus caught in a pond close to Ćáslavice village (N 49.255598 E 16.271148). Carapace length, wet mass (W) and sex of crayfish were recorded.

Crayfish were immersed individually to clove oil solution $\left(4 \mathrm{ml} \mathrm{L}^{-1}\right.$ for $10 \mathrm{~min}$ ) to remove attached branchiobdellids. Branchiobdellids started to escape from their host immediately after exposure. After $10 \mathrm{~min}$, the crayfish was removed from the solution and washed and the whole volume of the exposure tank was sieved $(0.3 \mathrm{~mm})$. The population of branchiobdellids from individual crayfish was then preserved in Eppendorf tubes containing 95\% ethanol. The number, biomass and species of branchiobdellids were determined in the laboratory under a stereomicroscope (Olympus SZX9, Hamburg, Germany), using analytical scales KERN ABT 220-4M (Kern \& Sohn GmbH, Balingen, Germany) and following the taxonomic keys by Neseman and Neubert (1999) and Gelder et al. (1994).

Non-parametric Mann-Whitney U tests were applied to reveal which crayfish species was more colonized by branchiobdellids using number and wet biomass of branchiobdellids. The data did not have a normal distribution, even after BOX-COX transformation (tested by the Shapiro-Wilks test). All statistical analyses were done using Statistica 12 (StatSoft Inc.).

\section{RESULTS}

In both sites, non-native crayfish species lived sympatrically with $A$. astacus, however sympatry had different patterns. Astacus astacus inhabited the upper stretch of the Černovický brook while $O$. limosus moved up from the lower stretch, pushing $A$. astacus upstream with only a thin contact zone. On the other hand, P. leniusculus co-occurred in the pond with $A$. astacus for more than 20 years, however the latter species also inhabited the source brook of the pond.

Two species of Branchiobdella (B. parasita (Braun, $1805)$ and B. pentadonta Whitman, 1882) were found on $P$. leniusculus, while only B. parasita was found on $O$. limosus. The mean number and biomass of branchiobdellids found on $P$. leniusculus and $O$. limosus were $26.0 \pm 15.9$ (range 6-66), and 64.8 \pm 27.7 (34-115) individuals, respectively, and $0.005 \pm 0.003$ and $0.016 \pm 0.011 \mathrm{~g}$, respectively. Branchiobdella parasita slightly prevailed $(58.7 \%)$ over B. pentadonta on P. leniusculus. Although individuals of $P$. leniusculus were significantly larger $(\mathrm{CL}=47.3 \pm 4.0 ; \mathrm{W}=26.9 \pm 6.9 \mathrm{~g})$ than individuals of $O$. limosus $(\mathrm{CL}=34.6 \pm 2.9 ; \mathrm{W}=12.0 \pm 3.2 \mathrm{~g})$, the number and biomass of branchiobdellids on $P$. leniusculus were significantly lower (Mann-Whitney; $\mathrm{Z}=7.68, \mathrm{P}<10^{-6}$ ) showing that individuals of $O$. limosus were more colonized by branchiobdellids. To illustrate this difference, the mean number of branchiobdellids per gram of crayfish was $1.0 \pm 0.5$ specimens $\mathrm{g}^{-1}$ in P. leniusculus, but $5.4 \pm 1.9 \mathrm{spec}-$ imens $\mathrm{g}^{-1}$ in O. limosus $\left(\mathrm{Z}=-6.69, \mathrm{P}<10^{-6}\right)$.

\section{DISCUSSION}

Here we reported European branchiobdellids (Branchiobdella spp.) found on naturalized populations of nonindigenous crayfish species, namely $O$. limosus and $P$. leniusculus (for the first time on the latter species). In both localities surveyed in this study, non-native crayfishes lived in sympatry with native $A$. astacus. Thus, $A$. astacus served most likely as a source of studied ectosymbionts, however we did not analyse the branchiobdellid community from A. astacus. Similarly, Jurek (2014) found branchiobdellids only on individuals of $P$. leniusculus living in sympatry with $A$. astacus. In Černovický brook, however, the high colonization level on O. limosus can most likely be explained by the decreasing number of original host $A$. astacus at the locality, where branchiobdellids were forced to find a new suitable host for that reason in order to survive. To illustrate this situation, the numbers of O. limosus and A. astacus captured at Černovický brook site were ca. 1300 and 90 specimens, respectively. On the other hand, at the Čáslavice pond locality, four thousand individuals of $P$. leniusculus and one thousand individuals of $A$. astacus were caught. This could mean that there were still enough native crayfish enabling survival of branchiobdellids, which had adopted the non-indigenous crayfish as a host. Moreover, the sympatry lasted here for more than 20 years and the community of branchiobdellids had not been faced with a rapid and critical decrease of its host, as in the Černovický brook site. The transmission of branchiobdellidans between sympatric species is known to be highly variable, most probably driven by cost/benefits relationships and explained in terms of fitness outcomes for individual ectosymbionts (Brown and Creed Jr, 2004; Skelton et al., 2015). In contrast, sympatry of native and non-native species does not automatically mean that non-native species were colonized by branchiobdellids. Adámek and Řehulka (2000) found sympatry of $A$. astacus and $O$. limosus in the small brook Pšovka and although individuals of $A$. astacus were highly colonized by Branchiobdella spp. (up to 362 individuals), the non-native $O$. limosus carried no branchiobdellids. It is a question whether these two species came into physical contact enabling host switching, or there 
could still be host preferences or other reasons, e.g. different activity, grooming behaviour, encounter of predators (Skelton et al., 2013; Farrell et al., 2014; Skelton et al., 2015). Nonetheless, the high infestation of $A$. astacus was most likely caused by decreasing numbers of this species, which had been dying of crayfish plague. Branchiobdella from dying individuals had probably transferred to live specimens. Reports of $O$. limosus having no branchiobdellidans are more frequent from different parts of Europe (Burba, 1997; Oberkofler et al., 2002; Klobučar et al., 2006). Only Duriš et al. (2006), Vogt (1999) and this study reported Branchiobdella spp. on O. limosus. Generally, more active crayfishes are colonized less than are less active species (Brown and Creed Jr, 2004), and non-native species (O. limosus and $P$. leniusculus) are considered as more active than native $A$. astacus (Lozán, 2000; Styrishave et al., 2007; Musil et al., 2010). Thus, probably only critical events increase the transmission rate for ectosymbiotic fauna to other possible hosts, which, otherwise, would not be infested at all. Further, specimens of $O$. limosus were taken and used for another study (Buřič et al., 2011) and after the end of this experiment (ca. six months) crayfish were found to be heavily colonized by adults and cocoons of Branchiobdella parasita (Fig. 1). It is important to note that, with respect to the relatively short life span of $O$. limosus (Smith, 1981),
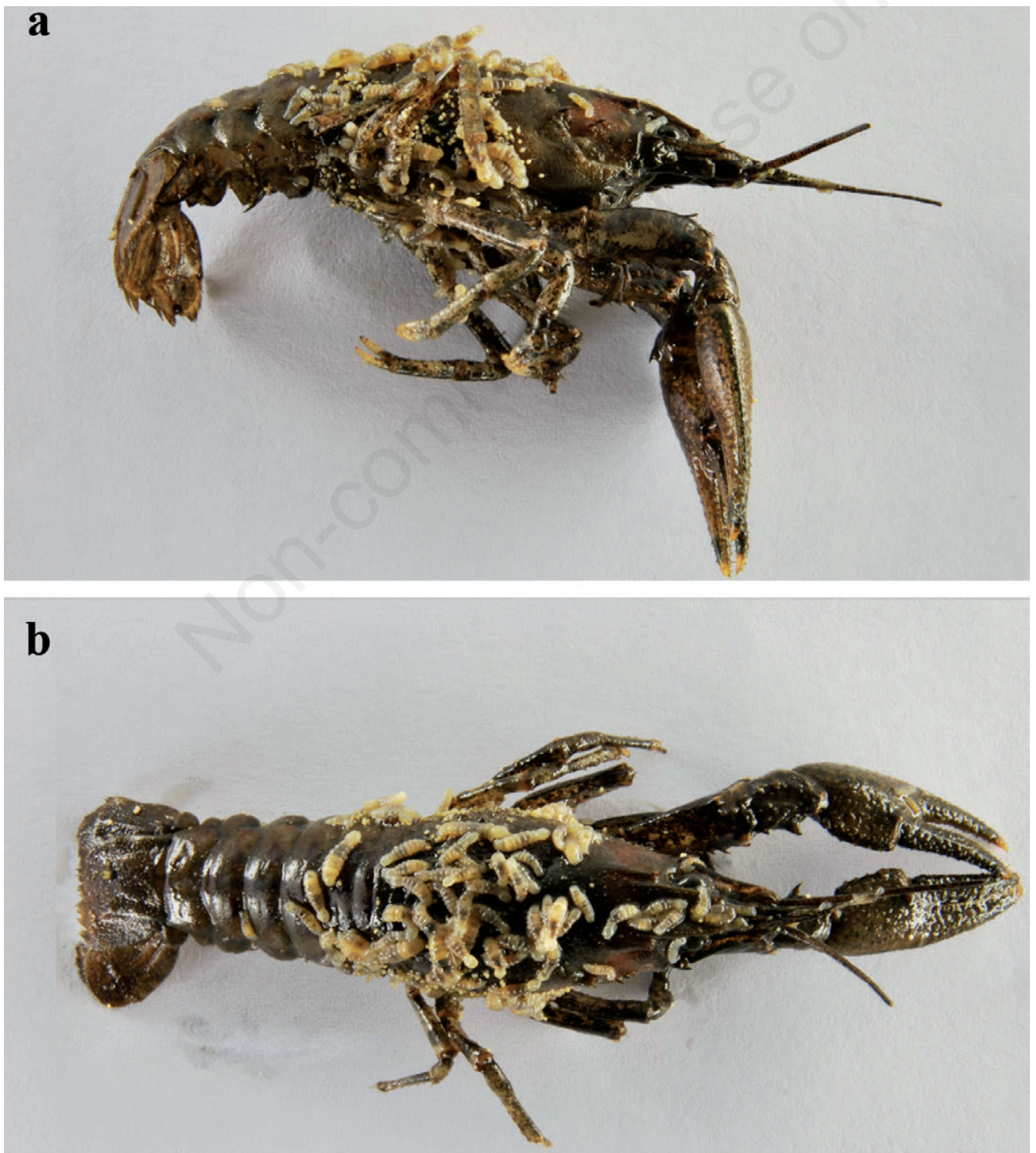

Fig. 1. The level of Branchiobdella parasitica colonization on Orconectes limosus: a) side view; b) dorsal view. 
the number of crayfish declined during the experiment and afterwards and branchiobdellids may have moved to live crayfish, resulting in quite a high number of Branchiobdella on the single remaining specimen depicted in Fig. 1. The population of B. parasita seemed to be viable and stable in the Černovický brook, using non-indigenous crayfish species as possible hosts.

\section{CONCLUSIONS}

We report here the occurrence of Branchiobdella spp. on the non-indigenous crayfish $O$. limosus and P. leniusculus. In both sites, non-native species lived sympatrically with native $A$. astacus, which most likely served as a source for the branchiobdellids. Although O. limosus is reported to be colonized less frequently by Branchiobdella spp., we found $B$. parasita establishing a viable population using this species. Furthermore, this is the first report of $P$. leniusculus with an established viable population of two Branchiobdella species (B. parasita, B. pentadonta). This also raises the question whether the native branchiobdellids colonize non-native invaders i) by chance; ii) naturally substitute for the disappearing native crayfishes in order to survive, since the colonization of a non-native host could be initiated by the gradual disappearance of native hosts; or iii) exhibit a natural dispersal strategy exploiting more possible niches for living. The same patterns can be expected also for future introduced epibionts colonizing native biota in order to survive.

\section{ACKNOWLEDGMENTS}

This study was supported by the Ministry of Education, Youth and Sports of the Czech Republic - projects "CENAKVA" (No. CZ.1.05/2.1.00/01.0024), "CENAKVA II" (No. LO1205 under the NPU I program) and the Grant Agency of the University of South Bohemia (project no. 012/2016/Z). We thank Dr. Julian Reynolds, Fellow Emeritus, The University of Dublin, for proofreading our manuscript.

\section{REFERENCES}

Adámek Z, Řehulka J, 2000. Crayfish diseases and commensals found in Czech Republic in 1998. Bulletin VÚRH Vodňany 1/2:28-32.

Brown BL, Creed Jr RP, 2004. Host preference by an aquatic ectosymbiotic annelid on 2 sympatric species of host crayfishes. J. N. Am. Benthol. Soc. 23:90-100.

Burba A, 1997. Stock, size composition, diseases and parasites of the crayfish, Astacus astacus, Astacus leptodactylus and Orconectes limosus in Lithuania. Freshwater Crayfish 11:213-218.

Buřič M, Hulák M, Kouba A, Petrusek A, Kozák P, 2011. A suc- cessful crayfish invader is capable of facultative parthenogenesis: a novel reproductive mode in decapod crustaceans. PloS One 6:e20281.

Carrillo D, Duncan R, Ploetz J, Campbell A, Ploetz R, Peña J, 2014. Lateral transfer of a phytopathogenic symbiont among native and exotic ambrosia beetles. Plant Pathol. 63:54-62.

Dudgeon D, Arthington AH, Gessner MO, Kawabata Z-I, Knowler DJ, Lévêque C, Naiman RJ, Prieur-Richard A-H, Soto D, Stiassny ML, 2006. Freshwater biodiversity: importance, threats, status and conservation challenges. Biol. Rev. 81:163-182.

Duriš Z, Horká I, Kristian J, Kozák P, 2006. Some cases of macroepibiosis on the invasive crayfish Orconectes limosus in the Czech Republic. B. Fr. Peche Piscic. 380/381:1325-1337.

Farrell KJ, Creed RP, Brown BL, 2014. Preventing overexploitation in a mutualism: partner regulation in the crayfish-branchiobdellid symbiosis. Oecologia 174:501-510.

Gallardo B, Clavero M, Sánchez MI, Vilà M, 2016. Global ecological impacts of invasive species in aquatic ecosystems. Global Change Biol. 22:151-163.

Gelder S, Williams B, 2015. Clitellata: Branchiobdellida, p. 551563. In: J. Thorp and D.C. Rogers (eds.), Ecology and general biology. Thorp and Covich's Freshwater Invertebrates. Academic Press.

Gelder SR, Delmastro GB, Ferraguti M, 1994. A report on branchiobdellidans (Annelida: Clitellata) and a taxonomic key to the species in northern Italy, including the first record of Cambarincola mesochoreus on the introduced American red swamp crayfish. Boll. Zool. 61:179-183.

Gelder SR, Delmastro GB, Rayburn JN, 1999. Distribution of native and exotic branchiobdellidans (Annelida: Clitellata) on their respective crayfish hosts in northern Italy, with the first record of native Branchiobdella species on an exotic North American crayfish. J. Limnol. 58:20-24.

Gelder SR, Parpet J-F, Quaglio F, 2012. First report of two North American branchiobdellidans (Annelida: Clitellata) or crayfish worms on signal crayfish in Europe with a discussion of similar introductions into Japan. Ann. Limnol.-Int. J. Lim. 48:315-322.

James J, Cable J, Richardson G, Davidson K, Mackie A, 2015. Two alien species of Branchiobdellida (Annelida: Clitellata) new to the British Isles: a morphological and molecular study. Aquatic Invasions 10:371-383.

Jurek L, 2014. Biology and invasive spreading of signal crayfish (Pacifastacus leniusculus) in the Vysočina Region. Bc. Thesis, University of South Bohemia.

Keller TA, 1992. The effect of the branchiobdellid annelid Cambarincola fallax on the growth rate and condition of the crayfish Orconectes rusticus. J. Freshwater Ecol. 7:165-171.

Klobučar GIV, Maguire I, Gottstein S, Gelder S, 2006. Occurrence of Branchiobdellida (Annelida: Clitellata) on freshwater crayfish in Croatia. Ann. Limnol.-Int. J. Lim. 42:251-260.

Lozán JL, 2000. On the threat to the European crayfish: A contribution with the study of the activity behaviour of four crayfish species (Decapoda: Astacidae). Limnologica 30:156-161.

Musil M, Buřič M, Policar T, Kouba A, Kozák P, 2010. Comparison of diurnal and nocturnal activity between noble crayfish (Astacus astacus) and spinycheek crayfish (Orconectes limosus). Freshwater Crayfish 17:189-193. 
Nesemann H, Neubert E, 1999. [Annelida, Clitellata: Branchiobdellida, Acanthobdellea, Hirudinea].[Book in German]. Spektrum Akademischer Verlag, Heidelberg: 178 pp

Oberkofler B, Quaglio F, Füreder L, Fioravanti M, Giannetto S, Morolli C, Minelli G, 2002. Species of Branchiobdellidae (Annelida) on freshwater crayfish in south Tyrol (northern Italy). B. Fr. Peche Piscic. 367:777-784.

Prenter J, Macneil C, Dick JT, Dunn AM, 2004. Roles of parasites in animal invasions. Trends Ecol. Evol. 19:385-390.

Skelton J, Creed RP, Brown BL, 2015. A symbiont's dispersal strategy: condition-dependent dispersal underlies predictable variation in direct transmission among hosts. P. Roy. Soc. B-Biol. Sci. 282:2015-2081.

Skelton J, Farrell KJ, Creed RP, Williams BW, Ames C, Helms BS, Stoekel J, Brown BL, 2013. Servants, scoundrels, and hitchhikers: current understanding of the complex interactions between crayfish and their ectosymbiotic worms (Branchiobdellida). Freshw. Sci. 32:1345-1357.
Smith DG, 1981. Life history parameters of the crayfish Orconectes limosus (Raf.) in southern New England. Ohio J. Sci. 81:169-172.

Styrishave B, Bojsen BH, Witthøfft H, Andersen O, 2007. Diurnal variations in physiology and behaviour of the noble crayfish Astacus astacus and the signal crayfish Pacifastacus leniusculus. Mar. and Fresh. Behav. Phy. 40:63-77.

Subchev M, 2014. The genus Branchiobdella Odier, 1823 (Annelida, Clitellata, Branchiobdellida): a review of its European species. Acta Zool. Bulg. 66:5-20.

Vogt G. 1999. Diseases of European freshwater crayfish, with particular emphasis on interspecific transmission of pathogens, p. 87-106. In: F. Gherardi and D.M. Holdich (eds.), Crayfish in Europe as alien species. How to make the best of a bad situation? A.A. Balkema.

Young W, 1966. Ecological studies of the Branchiobdellidae (Oligochaeta). Ecology 47:571-578. 